\title{
PEMBERDAYAAN MASYARAKAT PESISIR BERBASIS KELUARGA PERSEPEKTIF GENDER
}

\author{
Dendi Sutarto \\ Program Studi Ilmu Pemerintahan, Fakultas Ilmu Sosial dan Ilmu Politik, Universitas Riau Kepulauan, \\ Indonesia \\ dendi_sutarto@yahoo.co.id
}

\begin{abstract}
Abstrak
Kajian Pemberdayaan Masyarakat pesisir Batam, Karimun, dan Kepulauan Lingga berbasis keluarga bertujuan untuk mengetahui startegi, model dan faktor-faktor apakah yang mempengaruhi dalam pemberdayaan masyarakat pesisir. Analisis ini bermanfaat untuk memberikan rekomedasi solusi dan model untuk meningkatkan kemandirian dan pemberdayaan masyarakat secara berkenjutan. Kajian ini merupakan analsis metode deskriptif kualitatif dengan pendekatan gender. Faktor-faktor yang mempengaruhi pemberdayaan masyarakat secara berkelanjutan; Learning by doing, Problem solving, Self evaluation, Self development and coordination, Self selection, Self decisim independent variable. Konsep ini memberikan arah dalam pencapaian tujuan pemberdayaan masyarakat pesisi Batam, Lingga dan Karimun sebagai masyarakat pesisir kepulauan, dengan segenap potensi alam yang sangat besar, dengan itu semuan mereka membutuhkan sumber daya manusia sebagai kekuatan untuk mengelola potensi laut, perikanan, pertanian, home industry yang ada. Ada keyakinan besar dengan kekuatan sumber daya manusia sebagai word view atau cara mereka melihat dunia, potensi yang memiliki nilai sosial, ekonomis dan sebagainya sebagai kekuatan besar bagi mereka.
\end{abstract}

Kata kunci: Pemberdayaan, Masyarakat Pesisir, Keluarga, Gender.

\begin{abstract}
Empowerment analysis of coastal communities in Batam, Karimun, and Lingga Islands based on family aims to find out strategies, models and what factors influence the empowerment of coastal communities. This analysis is useful to provide a solution and model recommendations to improve the independence and empowerment of the community in a sequential manner. This study is a qualitative descriptive method analysis with a gender approach. Factors affecting sustainable community empowerment; Learning by doing, problem solving, self evaluation, self development and coordination, self selection, self decisive independent variables. This concept provides direction in achieving the objectives of empowering the coast community of Batam, Lingga and Karimun as island coastal communities, with all the enormous natural potential, therefore all they need human resources as a power to manage the potential of the sea, fisheries, agriculture, home industry there is. There is great confidence in the power of human resources as a word view or the way they see the world, the potential that has social, economic value and so on as a great power for them.

Keywords: Empowerment, Coastal Community, Family, Gender.
\end{abstract}




\section{PENDAHULUAN}

Dewasa ini masyarakat Batam dan pesisir Batam khususnya dihadapkan pada persoalan yang cukup rumit yaitu pengangguran, ketimpangan sosial dan ekonomi khusus (pasar bebas) disatu sisi kelihatan sangat maju dengan kota industrinya, namun disisilain ketimpangan sosial ekonomi di Batam cukup tinggi dimana sektor industri menjadi penyangga utama perekonomian masyarakat yaitu sebagai karyawan perusahaan, sedangkan lowongan dalam 5 tahun terakhir sangat terbatas sehingga imbasnya tingkat pengangguran dan kemiskinan semakin tinggi. Hal itu juga yang terjadi di masyarakat pesisir Batam, Karimun dan Kepulauan Lingga data Mei 2016 menunjukkan bahwa 56\% penduduk Kota Batam berpenghasilan rendah, sedangkan sepanjang Januari-Maret 2016 tercatat ada 49.237 warga miskin baru dan hampir miskin di kota industri Batam (Batam Pos, 9 Mei 2016).

Tingginya angka pertumbuhan penduduk dan persoalan sosial ekonomi membuat pembangunan masyarakat Batam dan wilayah pesisi tidak berlajan dengan baik, belum lagi tingginya angka pengangguran yang memicu tidakan kriminalisasi dimana-mana. Merujuk angkat dari data Badan Pusat Statistik (BPS) Kota Batam berdasarkan survei sosial ekonomi nasional 2015, distribusi persenstase pendapatan per kapita penduduk Kota Batam yang didominasi oleh kalangan pekerja dengan pendapatan Rp. 1-3 juta per bulan sebanyak 56,09 persen, sedangan penduduk yang berpengasilan kurang dari Rp. 1 juta per bulan berada di posisi kedua dengan persentase 36,42 persen.

Data di atas menunjukkan bahwa tingkat penganggunan dan kemiskinan di Kota Batam sangat tinggi, sehingga dampak terhadap kehidupan sosial dan rumah tangga sangat terasa. Seperti hasil observasi dan wawancara singkat penulis terhadap ibu rumah tangga pada 15 Januari 2018 yang lalu, "menurut mereka ekonomi sekarang sangat sulit, lapangan kerja begitu sulit di dapat, sedangkan biaya dan kebutuhan hidup di Batam sangat mahal, dan para suami lebih sering tidak bekerja alias menganggur". Dengan kondisi inilah konsep pemberdayaan masyarakat sangat penting untuk masyarakat Batam diharapkan mampu memberikan dampak perubahan dan pengutan sosial terhadap masyarakat miskin di Kota Batam dan masyarakat pesisir Batam yang notabene ada kaum nelayan dan rumah tangga, khusnya keluarga yang sangat terdampak.

Pengutan sosial pada sektor ekonomi dan sumber daya manusia menjadi titik tolak kekuatan sosial dalam rangka menciptakan kekuatan sosial bagi masyarakat pesisir Batam khusunya. Dalam konteks mencari solusi atas problem sosial dan kemiskinan telah banyak 
disampaikan para ahli pembangunan masyarakat miskin dan ketimpangan sosial yang mengangkat permasalahan ini ke permukaan. Karena sesungguhnya yang terjadi orang miskin tetap miskin, sebab persoalan yang berkaitan dengan produksi seperti kapasitas sumber daya manusia, modal soail, pelayanan publik dan kebijakan tetap sama dari tahun ke tahun, walaupun bentuknya programnya berbeda namun tetap tidak tepat memberikan dampak signifikan bagi masyarakat miskin.

Banyak proyek atau program pemerintah yang sudah dilakukan untuk mendorong pembangunan perekonomian masyarakat miskin. Proyek atau program tersebut dilakukan masing-masing departemen maupun antar departemen pemerintah. Pada umumnya programprogram yang digulirkan masih pada sebatas pemberian pelayanan kepada masyarakat dan sebagainya, namun tidak berdampak langsung pada perekonomian masyarakat dan tidak adanya konsep pemberdayaan yang jelas oleh pemerintah sehingga beberapa faktor yang mempengaruhi kegagalan program pemerintah masih terjadi hal tersebut antara lain, yaitu: (Batam Pos, 9 Mei 2016); (1) ketidaktepatan antara kebutuhan masyarakat dan bantuan yang diberikan (2) paket program tidak dilengkapi dengan ketrampilan yang mendukung (3) tidak ada kegiatan monitoring yang terencana (4) tidak ada kelembagaan di tingkat masyarakat yang melanjutkan program (5) tidak adanya program pemberdayaan masyarakat yang berkelanjutan bagi pengutaman sektor ekonomi masyarakat kecil atau usaha kecil menengah.

Belajar dari berbagai kegagalan tersebut program pemerintah dan berbagai kebijakan pengentasan kemiskinan yang belum sampai pada titik sasaran, khususnya pengutatan dan pemberdayaan berbasis keluarga sebagai ujung tombak bagi pembangunan sumber daya manusia dan pengutan ekonimi keluarga dalam perspektig kesadaran gender. Melalui berbagai model kegiatan pemberdayaan yang berkelanjutan dengan aspek lain seperti pelatihan untuk ketrampilan, pembentukan kelembagaan di tingkat masyarakat, penguatan keluarga sebagai basis kekuatan sosial, keberadaan petugas lapang untuk monitoring, pendampingan pemberdayaan dan pengutan masyarakat serta melibatkan berbagai unsur sosial dan listas sektor. Dengan kata lain beberapa program dikelola dengan pendekatan pemberdayaan masyarakat yang berkelanjutan sehingga hasil program lebih lama dimanfaatkan oleh masyarakat bahkan bertumbuh kembang memberikan dampak positif dan perubahan yang signifikan bagi kemandirian masyarakat.

Pemberdayaan adalah bagian dari paradigma pembangunan yang memfokuskan perhatiannya kepada semua aspek yang prinsipil dari manusia di lingkungannya yakni mulai 
dari aspek intelektual (Sumber Daya Manusia), aspek material dan fisik, sampai kepada aspek manajerial. Aspek-aspek tersebut bisa jadi dikembangkan menjadi aspek sosial-budaya, ekonomi, politik, keamanan dan lingkungan. Kemiskinan merupakan masalah kompleks yang dipengaruhi oleh berbagai faktor yang saling berkaitan, antara lain: tingkat pendapatan, kesehatan, pendidikan, akses terhadap barang dan jasa, lokasi, geografis, gender, dan kondisi lingkungan. Mengacu pada strategi nasional penanggulangan kemiskinan definisi kemiskinan adalah kondisi di mana seseorang atau sekelompok orang, laki-laki dan perempuan, tidak terpenuhi hak-hak dasarnya untuk mempertahankan dan mengembangkan kehidupan yang bermartabat. Definisi ini beranjak dari pendekatan berbasis hak yang mengakui bahwa masyarakat miskin mempunyai hak-hak dasar yang sama dengan anggota masyarakat lainnya.

Kemiskinan tidak hanya dipahami hanya sebatas ketidakmampuan ekonomi, tetapi juga kegagalan memenuhi hak-hak dasar dan perbedaan perlakuan bagi seseorang atau sekelompok orang dalam menjalani kehidupan secara bermartabat. Hak-hak dasar yang diakui secara umum meliputi terpenuhinya kebutuhan pangan, kesehatan, pendidikan, pekerjaan, perumahan, air bersih, pertanahan, sumberdaya alam, dan lingkungan hidup, rasa aman dari perlakukan atau ancaman tindak kekerasan dan hak untuk berpartisipasi dalam kehidupan sosial-politik, baik bagi perempuan maupun laki-laki.

Undang-Undang No. 32 Tahun 2004 pasal 167 menyatakan bahwa "Belanja daerah diprioritaskan untuk melindungi dan meningkatkan kualitas kehidupan masyarakat yang diwujudkan dalam bentuk peningkatkan pelayanan dasar, pendidikan, penyediaan fasilitas pelayanan kesehatan, fasilitas sosial dan fasilitas umum yang layak serta mengembangkan jaringan sosial. Dalam rangka penanggulangan kemiskinan sesuai Perpres No. 13 tahun 2009 dibentuk Tim Nasional Percepatan Penanggulangan Kemiskinan (TNP2K) yang bertanggungjawab mengkoordinasikan pengentasan kemiskinan di tingkat nasional. Berdasarkan Perpres No. 15 Tahun 2010 di tingkat Provinsi Dan Kabupaten/Kota juga telah dibentuk Tim Koordinasi Penanggulangan Kemiskinan (TKPK) sebagai salah satu mitra kerja TNP2K di tingkat daerah.

Pemerintah provinsi maupun kabupaten/kota juga memperoleh dana alokasi umum yang sebanding dengan tingkat kemiskinan di daerahnya. Berbagai subsidi juga telah diberikan oleh pemerintah pusat untuk mengurangi beban penduduk miskin. Dalam konteks 
regional kabupaten/kota beberapa program pemerintah kabupaten/kota secara langsung juga ditujukan untuk mengurangi kemiskinan di wilayahnya.

\section{TEORI PEMBERDAYAAN MASYARAKAT}

Istilah pemberdayaan merupakan terjemahan dari terminologi empowerment, di Indonesia istilah ini sudah dikenal pada tahun 1990-an di banyak NGo's, baru setelah Konferensi Beijing 1995 pemerintah menggunakan terminologi yang sama. Dalam perkembangannya istilah pemberdayaan telah menjadi wacana publik dan bahkan seringkali dijadikan kata kunci bagi kemajuan dan keberhasilan pembangunan masyarakat (Alfitri, 2011: 21). Pemberdayaan juga seringkali dimaknai sebagai matarantai proses kemandirian masyarakat atau upaya menghilangkan ketergantungan masyarakat kepada pemerintah atau pihak lain, sehingga dengan kata lain kemandirian secara totalitas mampu melahirkan pembangunan dan kesejahteraan.

Paradigma pemberdayaan adalah paradigma pembangunan manusia, yaitu pembangunan yang berpusat pada rakyat merupakan proses pembangunan yang mendorong prakarsa masyarakat berakar dari bawah (Goulet, dalam Kartasismita, 2005 dikutip dalam Alfitri, 2011). Upaya yang dilakukan berdasarkan pada akar persoalan yaitu meningkatkan kemampuan masyarakat dengan mengembangkan dan mendinamisasikan potensi dan memberdayakan. Pemberdayaan tidak hanya menumbuhkan dan mengembangkan nilai tambah ekonomi, tetapi juga nilai tambah sosial dan nilai budaya.

Robert Chambers, (dalam Kartasasmita, 1997) bahwa pemberdayaan masyarakat adalah sebuah konsep pembangunan ekonomi yang merangkum nilai-nilai sosial. Konsep ini merupakan paradigma baru pembangunan, yakni bersifat people centered, participatory, empowering and sustainable. Konsep ini lebih luas dari hanya semata-mata memenuhi kebutuhan dasar atau menyediakan mekanisme untuk mencegah proses pemiskinan lebih lanjut (sefty net). Pemberdayaan berasal dari bahasa Inggris empowerment, yang secara harafiah diartikan sebagai "pemberkuasaan" dalam arti pemberian atau penigkatan kekuasaan kepada masyarakat yang lemah atau tidak beruntung. Empowerment aims to increase the power of dis-advantaged, demikian menurut Jim Ife seperti dikutip (Suharto, 1997 dalam Alfitri, 2011:22). 
Swift dan Levin mengatakan pemberdayaan menunjuk pada usaha relocation of power melalui pengubahan struktur sosial (Suharto, 1997). Sedangkan Craig dan Mayo (1995:50 dalam Alfitri, 2011) mengatakan bahwa konsep pemberdayaan termasuk dalam pengembangan masyarakat dan terkait dengan konsep; kemandirian (self help), partisipasi (partisipation), jaringan kerja (networking) dan pemerataan (equity).

Tujuan dasar pemberdayaan adalah keadilan sosial dengan memberikan ketentraman kepada masyarakat serta persamaan politik dan sosial melalui upaya saling membantu dan belajar melalui pengembangan langkah kecil guna tercapainya tujuan yang lebih besar (Payne, 1997 dalam Alfitri, 2011).

Secara konseptual, pemberdayaan harus mencakup enam hal (Saraswati, 1997 dalam Alfitri, 2011), dan keenam hal ini menjadi kekuatan untuk mendorong keberlangsungan dan penguatan masyarakat pesisir di Batam, dan beberapa masyarakat pesisir di Kepulauan Riau yang telah penulis kunjungi secara langsung secara partisipatoris wilayah kepulauan seperti; ${ }^{1}$ di Pulau Karimun (Kundur, Kundur Utara, Karimun), dan juga Pulau Lingga (Lingga, Singkep, Dabo dan Senayang) yaitu:

\section{Learning by doing,}

Pemberdayaan sebagai proses belajar dan ada suatu tindakan konkrit yang terus-menerus, dan dampaknya dapat terlihat. Dalam hal ini pengutana harus dimulai dari keluarga dan kaum ibu sebagai fondasi kekuatan keluarga yang mencakup ekonomi kecil, home industry, pola pembentukan karakter dan penanaman nilai bagi anak-anaknya sebagai bentuk pertahanan keluarga. Pengembangan potensi lokal menjadi pekerjaan rumah dalam pemberdayaan masyarakat pesisir, pemanfaatan sumberdaya lokal dengan usaha kratif ibu-ibu dengan komunitas lokal.

\section{Problem solving}

Pemberdayaan harus memberikan arti terjadinya pemecahan masalah yang dirasakan krusial dengan cara dan waktu yang tepat. Salah satu tujuan utama pemberdayaan adalah pemecahan atas masalah yang dihadapi oleh komunitas masyarakat pesisir yang dihadapkan pada persolan kemiskinan, rendahnya pendidikan, kualitas SDM rendah,

\footnotetext{
${ }^{1}$ Data Penelitian penulis yang dilakukan di wilayah Pesisir Kepulauan Lingga khususnya di Pulau Dabo dan Singkep (2017), dan di Kepulauan Karumun khusunya di masyarakat pesisir Kundur, Kundur Utara, Buru dan Karirun (2018). Data Kependudukan dan Masyarakat Pesisir terkait dinamikanya di Kepulauan Riau disari dari hasil Diskusi dengan teman-teman Advokasi Kependudukan KKBPK Provinsi Kepulauan Riau, 2018 Kapasitas Penulis sebagai Anggota Advokasi Kependudukan KKBPK Provinsi Kepulauan Riau.
} 
daya kretifitas akan pengelolaan sumber daya yang seperti hasil laut, pertanian masih kurang, sehingga membutuhkan pola pendampingan yang riil sehingga mampu menstimulus keluarga untuk memiliki kekuatan ekonomi, sosial dan kemandirian dan membuat mereka tidak menggantungkan diri pada pihak ketiga sebperti toke atau bos pertanian, perikanan.

3. Self evaluation, pemberdayaan harus mampu mendorong seseorang atau kelompok tersebut untuk melakukan evaluasi secara mendiri. Ketika kegiatan pemebrdayaan berbasis keluarga dan komunitas sudah berjalan dengan baik, maka akan terbangun pola kekuatan sosial dan kekuatan ekonomi keluarga secara bertahap mampu menciptakan daya kratif, kesadaran akan kemandirian semakin kuat, sehingga pola solidaritas sosial dalam kontek ini menjadi kekuatan komunitas.

\section{Self development and Coordination}

Mendorong agar mampu melakukan pengembangan diri dan melakukan hubungan koordinasi dengan pihak lain secara lebih luas. Pada tahap ini kemandirian dan pengembangan telah berjalan dengan baik, kekuatan dan usaha yang telah berjalan pada keluarga dan komunitas seperti usaha kecil, home industri, pengelolaan ikan, sea food, hasil pertanian bisa dijual dengan memanfaatkan jaringan dan hubungan dengan pihak luar sehingga komoditas masyarakat pesisir memiliki nilai ekomonis yang tinggi mampu menopang keberlangsungan hidup keluarga dan menjadi kekuatan ekonomi, sosial, pendidikan.

\section{Self Selection}

Suatu kumpulan yang tumbuh sebagai upaya pemilihan dan penilaian secara mendiri dalam menetapkan langka kedepan. Ditahap ini kemandirian sosial, ekonomi telah berkembang dengan baik, keluarga dan komunitas telah menentukan arah kemana seharusnya mereka melangka, komunitas memiliki lokal knowledge sebagai word view; bagaimana mereka memandang dunia potensi yang ada disekeliling mereka yang bisa mereka kembangkan.

\section{Self Decisim}

Memilih tindakan yang tepat hendaknya dimiliki kepercayaan diri dalam memutuskan sesuatu secara mandiri.

Pemberdayaan merupakan upaya untuk meningkatkan harkat dan martabat masyarakat, dengan kata lain memberdayakan adalah memampukan dan memandirikan 
masyarakat. Dalam rangka pemikiran itu upaya memberdayakan masyarakat haruslah dilakukan dengan (Kartasasmita, 1997: 11-12 seperti dikutip dalam Alfitri, 2011):

1. Menciptakan suasana atau iklim yang memungkinkan potensi masyarakat berkembang.

2. Memperkuat potensi atau daya yang dimiliki masyarakat dengan didorong, baik kesempatan yang memungkinkan potensi atau daya masyarakat menjadi kekuatan bagi kehidupan sosialnya.

3. Pemberdayaan bukan hanya meliputi penguatan individu anggota masyarakat, melainkan juga penguatan pada dimensi pranatanya.

4. Meningkatkan partisipasi masyarakat dalam pengambilan keputusan, yang terkait dengan pemantapan, pembudayaan dan pengalaman demokrasi.

5. Memberdayakan juga mengandung arti melindungi, sehingga tidak ada ketimpangan dalam hal persaingan dan adanya pemerataan pembangunan.

Pemberdayaan masyarakat harus dengan konsep yang jelas untuk menghindari ketidaktepatan sasaran, terutama menyangkut masyarakat miskin atau hal yang paling krusial menyangkut basic needs, pemenuhan kebutuhan dasar, seperti dalam pandangan Paul Streeten dari Bank Dunia bahwa pendekatan basic needs dapat dilihat sebagai prinsip untuk mengorganisasi pemikiran dan usaha pembangunan, sehingga tujuan dan targetnya adalah mencapai kebutuhan dasar bagi kehidupan masyarakat (Fakih, 2003: 65).

Sebagai langka strategis pemberdayaan masyarakat, ada tiga pendekatan untuk perencanaan pengembangan masyarakat (community development approach) yaitu (Nindita, 2008: 63 lihat Alfitri, 2011):

\section{Development For Community}

Pencetus kegiatan pengembangan masyarakat adalah perusahaan yang mempunyai status sebagai pendonor, sedangkan komunitas target adalah sebagai objek kegiatan pengembangan masyarakat. Dampak dari kegiatan ini adalah ketergantungan dari komunitas terhadap perusahaan atau pemerintah untuk mencapai hasil akhir.

\section{Development With Community}

Dalam program ini kegiatan dirumuskan bersama-sama antara perusahaan dan masyarakat. Kedudukan perusahaan sebagai agen pembangunan, sedangkan komunitas adalah subjek sekaligus objek program pengembangan masyarakat. Tujuan dari program adalah memberi sumbangan pada proses pembangunan. Dampak positifnya, komunitas tidak 
sepenuhnya bergantung pada perusahaan atau pemerintah, akan tetapi dilatih untuk berswadaya.

\section{Development Of Community}

Karakter utama program ini adalah berorientasi pada pemenuhan kebutuhan komunitas. Tujuan akhirnya adalah pembangunan yang berproses. Di sini yang menjadi pencetus ide adalah komunitas sendiri, jadi komunitas yang mengidentifikasi kebutuhan dan program mereka. Dampak positifnya adalah membuat komunitas menjadi self-reliance, mereka sendiri yang terlibat dan sekaligus menentukan keberhasilannya.

\section{GENDER}

Gender sebagai perspektif untuk melakukan pemberdayaan masyarakat pesisir berbasis keluarga, artinya titik berat berat pemberdayaan dimulai dari keluarga dan komunitas yang rama terhadap perempuan. Keluarga dan perempuan diposisikan sebagai kekuatan dasar pembangunan keluarga, sumber daya manusia dan ekonomi.

Istilah gender berawal dari berbagai hal dan ketidakadilan terhadap perempuan, dari proses pembentukan, disosialisasikan, diperkuat dan dikonstruksi secara sosial dan kultural baik melaui ajaran agama maupun negara (Fakih, 2006: 9). Sehingga posisi perempuan sangat ambivalen di tengah realitas sosial politik patriarkal. Sehingga problem yang terjadi pada fenomena politik patriakal ini bagaikan matarantai yang berkelindan, yang berakar dari adanya konstruksi sosial, budaya, poitik dan konstruksi pemahaman agama yang terjadi dominasi dan diskriminasi terhadap perempuan dalam berbagai hal termasuk pola kemiskinan yang tercipta karena ketidakadilan gender (Parawansa, 2009: 3) .

Perbedaan gender sesungguhnya tidaklah menjadi masalah sepanjang tidak melahirkan ketidakadilan gender (gender inequalities) (Parawansa, 2009: 12). Namun yang menjadi masalah, ternyata perbedaan gender justru melahirkan berbagai ketidakadilan dan marginalisasi atau peminggiran terhadap yang lemah, baik bagi kaum laki-laki dan terutama bagi kaum perempuan. Sebagai upaya untuk mengidentifikasi sejauh mana perbedaan gender melahirkan ketidakadilan dapat dilihat melalui bagaimana akses, kesempatan, partisipasi, kontrol serta manfaat bagi kaum perempuan dalam mendapatkan hak asasi manusia terutama, hak hidup, pendidikan, agama dan akses publik (politik) secara adilan. Berbagai bentuk 
manifestasi ketidakadilan gender yang lahir dari perbedaan gender (gender differences), yakni:

Pertama adanya marginalisasi merupaka proses peminggiran yang mengakibatkan kemiskinan dalam berbagai dimensi kehidupan, rumah tangga, masyarakat dan negara. Kehidupan domestik perempuan tidak terlepas dari kekerasan dalam rumah tangga (domestic violences) yang dalam banyak hal dilegitimasi oleh keyakinan beragama (theologies) yang bias gender (Said, 2005: 13). Pada hal relasi suami istri adalah relasi kemitraan, bukan kekuasaan (Husein, 2007: 33). Dalam arti lain perempuan harus dipandang sama seperti lakilaki dalam mendapatkan hak-hak asasi manusia. Sementara dari berbagai disiplin ilmu Islam tradisional yang mapan yaitu; ilmu fiqh (ilm al-fiqh), kalam (ilm al-kalam), tasawuf (ilm altashawwuf) dan falsafah (al-falsafah), ilmu fiqh yang paling mendominasi pemahaman umat muslim. (madjid, 1995: 235) Sehingga perempuan seringkali hidup dalam tekanan teologis, namun ironisnya kekerasan domestik dianggap sebagai urusan "private" yang jauh dari ruang publik dan semata-mata dianggap urusan keluarga yang tidak boleh ada interpensi pihak lain, sehingga akan melanggengkan ketidak adilan.

Kedua, Subordinasi yang merupakan stigma bahwa perempuan tidak rasional (irrational) atau emosional sehingga perempuan tidak bisa tampil memimpin, sehingga terjadinya diskriminasi yang justru merugikan perempuan, perempuan hanya di dapur dan di kasur. Kalau kita mencoba melihat sejarah Indonesia memiliki bukti yang menunjukkan bahwa wanita bahkan sangat mungkin menjadi panglima perang seperti Cut Nyak Dien, Megawati menjadi pemimpin nasional, kita juga melihat bahwa Margareth Thatcher, Cory Aquino, Sirimavo Bandaranaike adalah seorang ibu rumah tangga (Soetrisno, 2001: 16-17). Karena makna pemimpin tidak hanya dimaknai secara sempit seperti yang di konstruksi selama ini sebatas pada kekuasaan dalam hal politik semata. Namun di sisi lain, pemimpin merupakan bentuk eksistensi di mana perempuan mempunyai peran, kedudukan berkuasa, berwenang dan mempunyai posisi tawar (bergaining position) dalam menentukan keputusan dalam kehidupan masyarakat. Dalam masyarakat yang ada sekarang justru dominasi politik, kultur, demokrasi dan ekonomi turut melegitimasi (Moose, 2007: 61) dan memperkuat tradisi subordinasi yang sangat patriarkal. Sehingga metamorfosa realitas sosial hanya berganti waktu dan tempat, di lain pihak sistem dan struktur serta tatanan nilai masih dominasi kultur masa lalu yang dilanggengkan. 
Ketiga, Stereotipe atau pelabelan negatif, bahwa perempuan secara kultural diperlakukan sebagai makhluk sekunder (secon dary creation) yang mempunyai tugas demestik serta memelihara lingkungan hidup lagi pasif (Murata, 1997: 7), sehingga itu bukanlah sifat alamiah perempuan melainkan sifat yang dikulturkan oleh sistem patriarki. Kemuadian dalam berbagai kondisi sifat dasar keperempuanan menjadi di nisbikan oleh berbagai kepentingan-kepentingan yang justru tanpa di sadari telah membentuk penjarapenjara kecil, dari wilayah domestik sampai publik. Secara kolektif jastifikasi seringkali dilebelkan pada kelompok-kelompok tertentu, terutama pada perempuan yang berawal dari asumsi-asumsi yang mengarah kepada ketidakadilan yang akhirnya merugikan perempuan karena imejnya sangat renah di masyarakat.

Bahwa perempuan memiliki hak inferior pada definisi mentalnya, walaupun status mereka yang seringkali dianggap rendah dalam berbagai interpretasi agama dan peran meraka hanya di gambarkan sebagai perempuan penggoda dan pusat nafsu syetan. Muncul streotipe bahwa perempuan "panjang rambut, tetapi pendek pikirannya" (Amin, 2003: 20) dan kesan seperti itu terjadi sampai sekarang yang merupakan representasi bahwa perempuan diciptakan hanyalah untuk melayani kaum laki-laki. Sehingga sistem relasi gender perempuan dan lakilaki cenderung dihindari untuk diubah dalam revivalisme Islam. Karena perubahan akan mengganggu kepentingan laki-laki yang mendominasi ataupun kelompok sosial, sehingga kelompok dominasi akan selalu menjaga status quo sistem relasi gender dengan jastifikasi teologis, struktur yang ahistoris (Hafids, 1992: 39).

Kemudian kekerasan terhadap perempuan tidak hanya secara fisik, namun belenggu perempuan atas nama teologis yang telah menjadi bagian akar kebudayaan, terinstitusi (struktur) (Wilmes, 2003: 91). Kenyataan ini merepresentasikan identitas, ketergantungan pada sistem patriarki. Kemudian di dunia saat ini perempuan memduduki klas dasar dalam masyarakat, karena dominasi posisi dan kontrol, politik, dan sumber daya lebih dikuasai oleh laki-laki (Aswad, 1978: 473).

\section{Konseptual}

Makna pendefinisian secara konseptual dalam konsep ini adalah untuk memberikan arah dalam pencapaian tujuan pemberdayaan masyarakat pesisi Batam, Lingga dan Karimun sebagai masyarakat pesisir kepulauan, dengan segenap potensi alam yang sangat besar, dengan itu semuan mereka membutuhkan sumber daya manusia sebagai kekuatan untuk 
mengelola potensi laut, perikanan, pertanian, home industry yang ada. Ada keyakinan besar dengan kekuatan sumber daya manusia sebagai word view atau cara mereka melihat dunia "mereka", potensi yang memiliki nilai sosial, ekonomis dan sebagainya sebagai kekuatan besar bagi mereka.

\section{Pemberdayaan Masyarakat}

Pemberdayaan menurut arti secara bahasa adalah proses, cara, perbuatan membuat berdaya, yaitu kemampuan untuk melakukan sesuatu atau kemampuan bertindak yang berupa akal, ikhtiar atau upaya (Depdiknas, 2003). Masyarakat adalah kesatuan hidup manusia yang berinteraksi menurut suatu sistem adat istiadat tertentu yang bersifat kontinyu, dan yang terikat oleh suatu rasa identitas bersama (Koentjaraningrat, 2009). Dalam beberapa kajian mengenai pembangunan komunitas, pemberdayaan masyarakat sering dimaknai sebagai upaya untuk memberikan kekuasaan agar suara mereka didengar guna memberikan kontribusi kepada perencanaan dan keputusan yang mempengaruhi komunitasnya (Foy, 1994). Pemberdayaan adalah proses transisi dari keadaan ketidakberdayaan ke keadaan kontrol relatif atas kehidupan seseorang, takdir, dan lingkungan (Sadan,1997).

Menurut Mubarak (2010) pemberdayaan masyarakat dapat diartikan sebagai upaya untuk memulihkan atau meningkatkan kemampuan suatu komunitas untuk mampu berbuat sesuai dengan harkat dan martabat mereka dalam melaksanakan hak-hak dan tanggung jawabnya selaku anggota masyarakat.

Pada Pemberdayaan pendekatan proses lebih memungkinkan pelaksanaan pembangunan yang memanusiakan manusia. Dalam pandangan ini pelibatan masyarakat dalam pembangunan lebih mengarah kepada bentuk partisipasi, bukan dalam bentuk mobilisasi. Partisipasi masyarakat dalam perumusan program membuat masyarakat tidak semata-mata berkedudukan sebagai konsumen program, tetapi juga sebagai produsen karena telah ikut serta terlibat dalam proses pembuatan dan perumusannya, sehingga masyarakat merasa ikut memiliki program tersebut dan mempunyai tanggung jawab bagi keberhasilannya serta memiliki motivasi yang lebih bagi partisipasi pada tahaptahap berikutnya (Soetomo, 2006).

\section{Masyarakat Pesisir}

Pendefenisian wilayah pesisir dilakukan atas tiga pendekatan, yaitu pendekatan ekologis, pendekatan administratif, dan pendekatan perencanaan. Dilihat dari aspek ekologis, 
wilayah pesisir adalah wilayah yang masih dipengaruhi oleh proses-proses kelautan, dimana ke arah laut mencakup wilayah yang masih dipengaruhi oleh proses-proses daratan seperti sedimentasi. Dilihat dari aspek administratif, wilayah pesisir adalah wilayah yanag secara administrasi pemerintahan mempunyai batas terluar sebelah hulu dari Kecamatan atau Kabupaten atau kota yang mempunyai hulu, dan kearah laut sejauh 12 mil dari garis pantai untuk Provinsi atau 1/3 dari 12 mil untuk Kabupaten/Kota. Sedangkan dilihat dari aspek perencanaan, wilayah pesisir adalah wilayah perencanaan pengelolaan dan difokuskan pada penanganan isu yang akan ditangani secara jawab (Naskah Akademik Pengelolaan Wilayah Pesisir, 2000) (Wahyudi, 2018).

Secara sosiologis, masyarakat pesisir memiliki ciri yang khas dalam hal struktur sosial yaitu kuatnya hubungan antara patron dan klien dalam hubungan pasar pada usaha perikanan. Biasanya patron memberikan bantuan berupa modal kepada klien. Hal tersebut merupakan taktik bagi patron untuk mengikat klien dengan utangnya sehingga bisnis tetap berjalan. Dari masalah utang piutang tersebut sering terjadi konflik, namun konflik yang mendominasi adalah persaingan antara nelayan dalam memperebutkan sumberdaya ikan yang jumlahnya terbatas. Oleh karena itu sangatlah pentingadanya pihak yang dapat mengembangkan sumberdaya laut dan mengatur pengelolaannya, (Waspada Dira Anuraga, 2012)

Dalam memahami karakteristik masyarakat pesisir, Redfield melihat bahwa kebudayaan folk tersebut dapat diteliti pada komunitas kecil. Dalam konteks masyarakat pesisir, masyarakat desa yang terisolasi (masyarakat pulau kecil) dan masyarakat desa pantai dapat berupa gambaran wujud komunitas kecil yang memiliki beberapa cara (Satria, 2015: 11-12):

1. Mempunyai identitas yang khas (distinctiveness);

2. Terdiri atas sejumlah penduduk dengan jumlah yang cukup terbatas (smallness), sehingga masih saling mengenal sebagai individu yang berkepribadian;

3. Bersifat seragam dengan diferensiasi terbatas (homogeinity); dan

4. Kebutuhan hidup penduduknya sangat terbatas sehingga semua dapat dipenuhi sendiri tanpa bergantung pada pasaran luar (allproviding self sufficiency).

Saat ini karakteristik masyarakat pesisir telah banyak mengalami perubahan sosial budaya, sehingga pola hubungan sosial ekonomi dan pendidikan telah banyak mengalami perkembangan yang cukup signifikan. Walaupun masyarakat pesisir berbeda dengan masyarakat petani yang hidup di daratan dengan spesifikasi pertanian dan dagang dengan 
pola hubungan sosial yang telah mengalami perubahan seiring masuknya teknologi seperti handphon, televisi dan transfortasi.

\section{Gender}

Gender berawal dari berbagai hal dan ketidakadilan terhadap perempuan, sehingga posisi perempuan sangat ambivalen di tengah realitas sosial kemasyarakatan yang sangat patriarkal. Sehingga problem yang terjadi pada fenomena sosial patriakal ini bagaikan matarantai yang berkelindan, yang berakar dari adanya pembentukan sescara sosial, budaya, poitik dan konstruksi pemahaman agama yang melahirkan dominasi dan diskriminasi terhadap perempuan (Parawansa, 2009: 3) dalam berbagai hal termasuk pola kemiskinan yang tercipta karena ketidakadilan gender.

Perbedaan gender sesungguhnya tidaklah menjadi masalah sepanjang tidak melahirkan ketidakadilan gender (gender inequalities) (Parawansa, 2009: 12). Namun yang menjadi masalah, ternyata perbedaan gender justru melahirkan berbagai ketidakadilan dan marginalisasi atau peminggiran terhadap yang lemah, baik bagi kaum laki-laki dan terutama bagi kaum perempuan. Sebagai upaya untuk mengidentifikasi sejauh mana perbedaan gender melahirkan ketidakadilan dapat dilihat melalui bagaimana akses, kesempatan, partisipasi, kontrol serta manfaat bagi kaum perempuan dalam mendapatkan hak asasi manusia terutama, hak hidup, pendidikan, agama dan akses publik (politik) secara adilan. Berbagai bentuk manifestasi ketidakadilan gender yang lahir dari perbedaan gender (gender differences)

Atribut jenis kelamin secara kultur menjadi faktor penting dalam melegitimasi peran gender seseorang. Sehingga ketika jenis kelamin kelihatan, maka konstruksi sosial budaya telah terjadi melalui persepsi laki-laki dan perempuan. Kemudian atribut ini juga senantiasa digunakan untuk menentukan hubungan relasi gender, seperti fungsi, peran dan status lakilaki dan perempuan dalam masyarakat

\section{KESIMPULAN}

Konsep ini memberikan arah dalam pencapaian tujuan pemberdayaan masyarakat pesisi Batam, Lingga dan Karimun sebagai masyarakat pesisir kepulauan, dengan segenap potensi alam yang sangat besar, dengan itu semuan mereka membutuhkan sumber daya manusia sebagai kekuatan untuk mengelola potensi laut, perikanan, pertanian, home industry yang ada. Ada keyakinan besar dengan kekuatan sumber daya manusia sebagai word view atau cara mereka melihat dunia "mereka", potensi yang memiliki nilai sosial, ekonomis dan 
sebagainya sebagai kekuatan besar bagi mereka. Dengan demikian maka model-model pemberdayaan masyarakat ini bisa menjadi model yang memberikan dampak bagi perubahan sosial ekonomi, dan pendidikan yang pada akhirnya mampu melahirkan kekuatan-kekuatan sebagai modal keberlangsungan hidup keluarga, komunitas dan masyarakat pesisir dengan potensi yang sangat luar biasa.

\section{DAFTAR PUSTAKA}

Abdullah, Irwan dkk. (2002). Islam dan Konstruksi Seksualitas. Yogyakarta: PSW IAIN Yogyakarta, The Fort Foundation dan Pustaka Pelajar.

Abdullah, Irwan. (2006). Sangkan Peran Gender. Yogyakarta: Pusat Studi Kependudukan UGM kerjasama Pustaka Pelajar.

Alfitri. (2011). Community Development Teori dan Aplikasi. Yogyakarta: Pustaka Pelajar

Amin, Qosim. (2003). The New Women: A Documen in The Early Debate of Egyption Feminisme, (terj),. Syariful Alam, Sejarah Penindasan Perempuan, Menggugat "Islam Laki-laki” Menggurat "Perempuan baru”. Yogyakarta: IRCiSoD, 2003

Arikunto, Suharsimi. (2002). Prosedur Penelitian Suatu Pendekatan Praktek. Jakarta: PT Rineka Cipta.

Aswad, Barbara C. (1978). Women, Class, and Power: Examples from the Hatay, Turkey, within, Lois Beck and Nikki Keddie (ed), To the Women of the Muslim Word Harvard University Press.

Berry, David. (2003). The Principle of Sociology, (terj), Paulus Wirutomo, Pokok-pokok Pikiran Dalam Sosiologi. Jakarta: PT Raja Grafindo Persada.

Berger, Peter L. (1991). The Sacred Canopy, (terj), Hartono, Langit Suci Agama Sebagai Realitas Sosial. Jakarta: LP3ES.

Berger, Peter L. dan Thomas Luckman. (1990). The Social Contruction of Reality, (terj), Hasan Basri, Tafsir Sosial Atas kenyataan. Jakarta: LP3ES.

Fakih, Mansur. (2006). Analisis Gender dan Tranformasi Sosial. Yogyakarta: Pustaka Pelajar.

Pustaka Pelajar

(2003). Runtuhnya Teori Pembangunan dan Globalisasi. Yogyakarta: . (2004). Masyarakat Sipil Untuk Transformasi Sosial. Yogyakarta: Pustaka Pelajar.

Furchan, Arief. (1992). Pengantar Metoda Penelitian Kualitatif. Surabaya: Usaha Nasional. 
Gilbert, Alan \& Josep Gugler. (1996). Urbanisasi dan Kemiskinan di Dunia Ketiga. Yogyakarta: Tiara Wacana.

Hadi, Sutrisno. (1982). Metodologi Reserch, Jakarta: Yasbit Fakultas Psikologi UGM.

Illich, Ivan. (2002). Gender, (terj), Omi Intan Naomi, Matinya Gender (Yogyakarta: Pustaka Pelajar.

Koentjaraningrat. (1983). Penelitian Masyaraka, Jakarta: PT Gramedia. . (1984). Kebudayaan Jawa. Jakarta: Balai Pustaka

Muhammad, Husein. (2007). Islam Agama Ramah Perempuan. Yogyakarta: LkiS.

Meyer-Wilmes, Hedwig. (2003). Kekerasan Besar-besaran Tehadap Perempuan atas Nama Agama, dalam, Win Beuken, dkk, Religion as a Source of Violence? (terj), Imam Baehaqie, Agama Sebagai Sumber Kekerasan, Yogyakarta: Pustaka Pelajar.

Moleong, Lexi J. (2000). Metodelogi Penelitian Kualitatif, Bandung: PT Remaja Rosdakarya.

Mosse, Julia Cleves. (2007). Half The Word, Harf A Chance, An Introduction to Gender and Development, (terj), Hartian Silawati, Gender dan Pembangunan Yogyakarta: RIFKA ANNISA Women's Crisis Center dengan Pustaka Pelajar.

Mubarak, Z. (2010). Evaluasi Pemberdayaan Masyarakat Ditinjau Dari Proses Pengembangan Kapasitas Pada Program PNPM Mandiri Perkotaan Di Desa Sastrodirjan Kabupaten Pekalongan.Tesis. Program Studi Magister Teknik Pemberdayaan Wilayah Dan Kota. Undip. Semarang.

Nottingham, Elizabeth K. (2002). Religion and Sociaty, (terj), Abdul Muis Naharong, Agama dan Masyarakat, Jakarta: Rajawali Perss.

Parker, Richard and Peter Aggleton. (2003). Culture, Society and Sexuality A Reader London: UCL Press.

Patra, Nezar \& Andi Arif. (2003). Antonio Gramsci, Nagara dan Hegomoni, Yogyakarta: Pustaka Pelajar.

Poloma, Margaret M. (2003). Contemporery Sociolocical Theory, (terj), Yosagama, Sosiologi Kontemporer, Jakarta: Rajawali Press.

Ridwan. (2006). Kekerasan Berbasis Gender, Purwokerto: Pusat Studi Gender STAIN Purwokerto kerjsama Fajar Pustaka Yogyakarta.

Ritzer, George. (2004). a multiple paradign science, (terj), Alimandan, Sosiologi Ilmu Berparadigma Ganda, Jakarta: Rajawali Pers. 
Ritzer, George dan Douglas J. Goodman. (2004). teori Sosiologi Modern, (terj), Alimandan Jakarta: Rajawali Perss.

Ritzer, George. (2005). The Postmodern Society Theory, terj. Muhammad Taufik, Teori Sosial Postmodern, Yogyakarta: Juxtapose bekerjasama Kreasi Wacana

Sadan, Elisheva. (1997). Empowerment and Community Planning: Theory and Practice of People-Focused Social Solutions. Tel Aviv: Hakibbutz Hameuchad Publishers.in Hebrew. [e-book].

Soetrisno, Loekman. (2001). Kepemimpinan Wanita Dari Perspektif Sosial Budaya, dalam, Nureyahbani Katjasungkana, dkk, Potret Perempuan Tinjauan Politik, Ekonomi, Hukum di Zaman Orde Baru, Yogyakarta: PSW UMY bekerjasama Pustaka Pelajar.

Soehadha, Moh. (2004). Pengantar Metode Penelitian Sosial Kualitatif, Buku Daras, Yogyakarta: Tidak Diterbitkan.

Tibi, Bassam. (1999) Islam and the Cultural Accommodation of Social Change, (terj), Misbah Zukfah Ellizabet dan Zainul Abas, Islam Kebudayaan dan Perubahan Sosial, Yogyakarta: Tiara Wacana. 